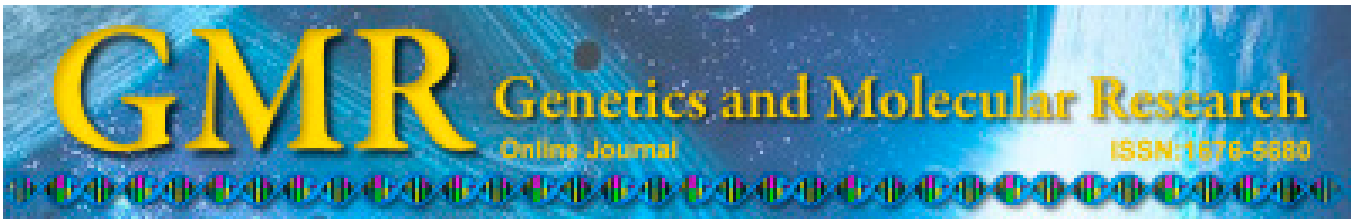

\title{
Carcass and meat quality traits in Nellore and F1 Nellore-Araguaia crosses
}

\author{
N.V. Costa ${ }^{1}$, C. Aboujaoude ${ }^{2}$, G.S. Vieira ${ }^{1}$, V.V. Paiva ${ }^{1}$, R.A. Moraes Neto ${ }^{3}$, \\ V.S. Gondim ${ }^{2}$, L.R. Alves ${ }^{4}$, M.C.L. Torres ${ }^{5}$ and R.C. Antunes ${ }^{1}$ \\ ${ }^{1}$ Faculdade de Medicina Veterinária, Universidade Federal de Uberlândia, \\ Uberlândia, MG, Brasil \\ ${ }^{2}$ Faculdade de Ciências Agrárias e Veterinárias, \\ Universidade Estadual de São Paulo, Jaboticabal, SP, Brasil \\ ${ }^{3}$ Associação Brasileira dos Criadores da Raça Araguaia, Araçatuba, \\ SP, Brasil \\ ${ }^{4}$ Serviço Nacional de Aprendizagem Rural, Palmas, TO, Brasil \\ ${ }^{5}$ Departamento de Engenharia de Alimentos, \\ Universidade Federal de Goiás, Goiânia, GO, Brasil \\ Corresponding author: N.V. Costa \\ E-mail: naianevcosta@gmail.com \\ Genet. Mol. Res. 14 (2): 5379-5389 (2015) \\ Received May 13, 2014 \\ Accepted November 13, 2014 \\ Published May 22, 2015 \\ DOI http://dx.doi.org/10.4238/2015.May.22.7
}

\begin{abstract}
We evaluated and compared carcass traits and meat quality in Nellore cattle and F1 crosses between Nellore and Araguaia, where 17 individuals were from the Nellore group and 19 were $1 / 2$ Nellore and $1 / 2$ Araguaia crosses. All animals belonged to the same birth season and were raised in pasture systems under the same nutritional, environmental, and management conditions. When the animals reached slaughter weight, they were taken to an industrial slaughterhouse where food was not provided for $24 \mathrm{~h}$ (free access to water); they were then stunned, bled, the leather was removed, and they were eviscerated. The carcasses were weighed (hot weight), kept in chilled storage for approximately $24 \mathrm{~h}$ at $4^{\circ} \mathrm{C}$, and weighed again to obtain the chilled carcass weight. Carcass yield, carcass length, carcass width, leg length,
\end{abstract}


thigh perimeter, loin eye area (LEA), retail cuts, cooling loss, $\mathrm{pH}$, fat depth, marbling rate, intramuscular fat, color, and shear force were analyzed and sensory analysis of the meat was conducted. Significant differences $(\mathrm{P}<0.05)$ were observed for the following variables: slaughter weight, hot and chilled carcass weights, carcass and leg lengths, thigh perimeter, LEA, retail cuts, and lightness $\left(\mathrm{L}^{*}\right)$, where the $1 / 2$ Nellore $1 / 2$ Araguaia individuals showed higher means for all of these traits, except leg length and L*. Therefore, crossbreeding between Nellore and Araguaia did not affect the meat's sensory characteristics, but contributed to an improvement in carcass traits, providing an alternative for farmers that aim for good meat quality, with a higher meat percentage.

Key words: Bos indicus; Bos taurus; Loin eye area; Sensory analysis; Shear force; Slaughter weight

\section{INTRODUCTION}

The Araguaia breed was developed with the intention of improving livestock productivity, and to possibly obtain higher meat production. The genetic makeup of the Araguaia breed includes Blond D'Aquitane (15/32), Nellore (8/32), and Caracu (9/32) breeds. The Araguaia Race was certified by the Brazilian Ministry of Agriculture, Livestock and Food Supply (MAPA) and has 610 registered animals. These animals are genetically superior in terms of productivity and are adapted to the harsh tropical climate, providing an alternative for the development and productivity of beef cattle.

According to the Brazilian Association of Meat Exporting Industries (ABIEC, 2013), Brazil has approximately 209 million cattle, of which $80 \%$ is composed of zebu breeds (Bos indicus), animals that have proven robustness and are adapted to the predominant environment in Brazil. Among these zebu breeds, the Nellore is predominant, composing $90 \%$ of the breed. Because the use of European purebreds (known for high growth rates in beef cattle production systems), is limited in Brazil due to large environmental differences between temperate and tropical climates (Lopes et al., 2012), the use of industrial crossings has increased significantly in recent years in order to increase beef cattle productivity (Arrigoni et al., 2004).

The aim of genetic crossing is to combine and complement economically important traits and benefit from the resulting heterosis (Restle et al., 2002). Crosses are used to produce top quality meat and the use of crosses increases with the expansion, intensification, and modernization of production systems, seeking to reduce slaughter age, increase carcass weight, and increase muscle gain with greater biological efficiency and development of functional properties (Pereira et al., 2009).

In addition to relatively early deposition of subcutaneous fat, the Nellore breed also has greater carcass yields (Restle et al., 2002). However, the Nellore breed also has low muscle expression when compared to European breeds (Restle et al., 2000). Therefore, in industrial crossings, European breeds, which have higher weight gain and greater carcass and meat qualities, are typically recommended for use in the paternal line. Regarding the maternal line, zebu breeds have been shown to exhibit adaptations to tropical environments, robustness, and lower maintenance requirements (de Souza et al., 2010). 
Perotto et al. (2000) confirmed that crosses between European and zebu breeds resulted in greater weight and improved meat quality in these animals. According to Freitas et al. (2008), a carcass that meets consumer requirements shall be split proportionally between the sections of which it is composed, in other words, a substantial portion of meat, a minimum number of bones, and an adequate amount of fat. Given these considerations, the present study aimed to evaluate and compare carcass and meat quality traits of Nellore and F1 progeny resulting from Nellore and Araguaia crosses.

\section{MATERIAL AND METHODS}

Thirty-six males were divided into two genetic groups: 17 Nellores with a mean initial body weight of $333.94 \pm 25.09 \mathrm{~kg}$ and an average age of 19 months in one group and $191 / 2 \mathrm{Nel}-$ lore $\mathrm{x} 1 / 2$ Araguaia crosses with a mean initial body weight of $380.35 \pm 18.59 \mathrm{~kg}$ and an average age of 21 months in the second group. The animals belonged to the same property in the municipality of Torixoréu-MT, at an altitude of $335 \mathrm{~m}$, with a hot and humid tropical climate, an average annual rainfall of $1750 \mathrm{~mm}$ (with greatest intensity from December to February), and an average annual temperature of $32^{\circ} \mathrm{C}$ (maximum $40^{\circ} \mathrm{C}$, minimum $0^{\circ} \mathrm{C}$ ) (City Brazil, 2013).

The animals were weaned at 8 months of age and were then maintained in pastures (Brachiaria Brizantha) without supplementation. Surgical castration was performed on all animals at the beginning of the experiment. These animals were finished on pasture from May 2012 to February 2013 under the same nutritional, environmental, and management conditions. From early November until their departure to the industrial slaughterhouse, the animals were supplemented using a feed trough with a concentrate equivalent to approximately $1.5 \%$ of the body weight per animal. The concentrate contained $83.9 \%$ corn, $12 \%$ soybean meal, $0.5 \%$ urea, $0.4 \%$ dicalcium phosphate, $1.5 \%$ limestone, and $1.7 \%$ sodium chloride, with $66 \%$ of total digestible nutrients (TDN) and $13.5 \%$ of crude protein. The average supplement intake of animals during the experimental period was $6 \mathrm{~kg}$ of concentrate per animal per day.

When all the animals reached a minimum weight of $480 \mathrm{~kg}$, they were weighed (slaughter weight) after a fasting period of $16 \mathrm{~h}$. Following this, they were fed and then transported to an industrial slaughterhouse $100 \mathrm{~km}$ away. At the industrial slaughterhouse, food was withdrawn for $24 \mathrm{~h}$ (with free access to water) and animals were slaughtered according to the Brazilian Industrial and Sanitary Regulation of Animal Product Inspection (BRAZIL, 1997). Animals were stunned by concussion, the jugular vein was cut, the leather was removed, and they were eviscerated. The carcasses were then identified, washed, divided into two halves with the aid of a chainsaw, weighed again (hot carcass weight) and taken to chilled storage for approximately $24 \mathrm{~h}$ at $4^{\circ} \mathrm{C}$, and then weighed again (chilled carcass weight). The carcass yield (in percentage) was obtained by dividing hot carcass weight by slaughter weight, and cooling loss (in percentage) was obtained by subtracting 100 and by chilled carcass weight/hot carcass weight, according to Bridi (2002).

Measurements of carcass length, carcass width, leg length, and thigh perimeter were then collected. Carcass length was measured from the cranial edge of the first costae to the cranial edge of the pubic symphysis, and carcass width was measured from the cranial edge of the sternum to between the fifth and sixth cervical vertebrae. The length of the leg was measured between the midpoint of the tarsometatarsal joint and the front edge of the ischiopubic symphysis. The thigh perimeter was measured between the lateral and medial sides of the upper thigh, according to Bridi (2002). 
The $\mathrm{pH}$ of the Longissimus dorsi muscle $24 \mathrm{~h}$ postmortem was estimated using a Testo ${ }^{\circledR}$ 230 model $\mathrm{pH}$ meter, within calibration validity. Next, the half carcass was cut in between the twelfth and thirteenth costae, in which the loin eye area (LEA) was analyzed by tracing the outline of the Longissimus dorsi muscle to greaseproof paper and later measuring the area using $\mathrm{mm}$ graph paper. Fat depth was measured in the same region at 3/4 the length of the loin from the bone (Luchiari Son, 2000) using a caliper with an accuracy of $0.005 \mathrm{~cm}$. Marbling was rated using photographic standards, according to AMSA (2001), as cited by Felício (2010).

The total amount of boneless, trimmed ( $5 \mathrm{~mm}$ of fat) Brazilian retail cuts, excluding short ribs, was obtained using the following equation:

$$
\mathrm{BRC}=60.33-0.015 . \mathrm{HCW}-0.462 . \mathrm{FD}+0.110 . \mathrm{LEA} \quad \text { (Equation 1) }
$$

where, $B R C$ is the percentage of Brazilian retail cuts (\%), $H C W$ is the hot carcass weight $(\mathrm{kg})$, $F D$ is the fat depth (mm), and $L E A$ is the loin eye area (cm2) (Felício and Allen, 1981/1982).

Samples of $2.5 \mathrm{~cm}$ were collected from the caudal portion of the L. dorsi muscle for intramuscular fat, shear force, color, and sensory analyses. For all evaluated animals, the first sample taken was used for intramuscular fat analysis, the second and the third were used for sensory analysis, and the fourth for shear force and color analyses. The samples were identified, vacuum packed and frozen. Data and samples were always taken from the left carcass.

Intramuscular fat analyses were conducted at the Animal Nutrition Laboratory of UFU. The muscular portions of the samples were thawed under refrigeration at $5^{\circ} \mathrm{C}$ and cut into strips, to facilitate the withdrawal of excessive humidity according to the method described by Silva et al. (2002), for dry matter and humidity analyses. Then, the intramuscular fat analyses were carried out according to the Analytical Methods for determining ethereal extract-Soxhlet method described in the Brazilian Compendium of Animal Nutrition (ANFAR, 2009).

The color analysis was undertaken at the Physical Chemistry Laboratory of UFG. The samples were thawed under refrigeration at $5^{\circ} \mathrm{C}$, the packages were then opened, and the samples were individually wrapped with transparent poly-vinyl chloride (PVC) films. The color was measured using a HunterLab ColorQuest II $^{\circledR}$ colorimeter, indicating L* (brightness), a* (redness) and b* (yellowness) parameters, carried out in quadruplicate. Abularach et al. (1998) classified meat as dark when $L^{*}<29.68$ and light when $L^{*}>38.51$; a redness value $\left(a^{*}\right)<14.83$ is considered low and $a^{*}>29.27$ as high, and a yellowness value $\left(b^{*}\right)<3.40$ is low and $\mathrm{b}^{*}>8.28$ is high.

Following color analysis, the samples were transferred to the Meat Laboratory and were packed and sealed in polyester plastic bags. The samples were then baked in an electric oven between 170 and $180^{\circ} \mathrm{C}$ for $35 \mathrm{~min}$, to ensure that the internal beef temperature reached $70^{\circ} \mathrm{C}$. The samples were then cooled to $25^{\circ} \mathrm{C}$ and cut parallel to the direction of the muscle fiber, thus, obtaining sub-samples of $1.5 \mathrm{~cm}$ wide, $1.5 \mathrm{~cm}$ thick, and $2.5 \mathrm{~cm}$ long (the direction of the fiber corresponds to the thickness of the sample). From each sample, nine sub-samples were taken for the analyses. Tenderness was evaluated using the maximum shear force technique. This analysis was performed at the Multiuser-Rheology and HPLC Laboratory at UFG. Maximum shear force was measured using a Warner-Bratzler blade and a guillotine probe attached to a TA-XT Plus ${ }^{\circledR}$ texturometer (Stable Micro Systems). The texturometer was calibrated for pre-test at a speed of $2 \mathrm{~mm} / \mathrm{s}$, test at $2 \mathrm{~mm} / \mathrm{s}$, and post-test at $10 \mathrm{~mm} / \mathrm{s}$, with the 
device programed to run $25 \mathrm{~mm}$ by the end of the three phases.

The sensory analysis was held at the Sensory Analysis Laboratory at UFG. First, recruitment was conducted using questionnaires with volunteer students and staff at UFG. Pre-selected volunteers were then trained by providing them with the following definitions: succulence, perception of the amount of fluid released from the sample in the mouth after the first chew; tenderness, the force required to compress a piece of meat between the molar teeth at the sixth bite; flavor, characteristic of the tenderloin; and overall quality, pleasant combination of all features.

For a greater training result, extreme analyzed traits were presented to volunteers (extremely dry, moderately succulent, hard, tender, savory, and insipid). After training, cuts of striploin and round steak were served to the tasters in four replicates each, encoded with three-digit numbers. They evaluated the samples for succulence, tenderness, flavor, and overall quality using the Sensory Analysis form with an unstructured scale of $9 \mathrm{~cm}$. The panelists that were able to identify that the round steak was less succulent compared to the striploin and that the striploin was more tender than the round steak were selected, totaling 12 panelists.

To perform sample analysis, the animals were divided into eight groups, four groups of Nellore and four groups of $1 / 2$ Nellore $\mathrm{x} 1 / 2$ Araguaia. A random draw was held to determine which animals would be in each group and the order of group evaluation.

The samples were first dry salted at $2 \%$ of the sample weight, cooked under the same conditions for shear force analysis, stored in a water bath at $60^{\circ} \mathrm{C}$, and served randomly to the panelists, who rated the still warm meat. The same Sensory Analysis form used in the panelist selection stage was used, and the samples were coded once again with three digit numbers so that meat identification was not possible. The score given by the panelists using the form was measured in $\mathrm{cm}$ and recorded for each evaluated parameter (succulence, tenderness, flavor, and overall quality). A sample size of 96 responses for each genetic group resulted from the 12 panelists who participated in this experiment, each evaluating 4 groups in duplicate for each genetic group.

The t-test was used to analyze the independent samples with normal data, the MannWhitney test was used for marbling score data, and the nonparametric Friedman test was used for qualitative variables obtained in the sensory analysis. These tests were conducted in order to ascertain whether the genetic groups were statistically significant at the 5\% level using the Action tool (Equipe Estatcamp, 2014) in R (R Core Team, 2013). The Pearson correlation coefficient was used to evaluate the relationship between variables at the $5 \%$ significance level, the carcass traits and meat quality were combined for Nellore and F1 crosses between Nellore and Araguaia. The variables that were significantly correlated with hot carcass weight were corrected for covariance using the following equation:

Corrected value $=$ initial value $-[$ (linear slope). (hot carcass weight - average hot carcass weight)]

(Equation 2)

when calculating the slope of the linear regression, the abscissa is the hot carcass weight and the ordinate is the variable to be corrected.

The experiment conducted in the current study was approved by the Comitê de Ética no Uso de Animais with CEUA/UFU 007/13 protocol registration.

\section{RESULTS}

Slaughter weight, chilled carcass weight, carcass yield, carcass length, carcass width, 
leg length, thigh perimeter, LEA, redness $\left(\mathrm{a}^{*}\right)$, and shear force values were corrected for covariance with hot carcass weight. No significant differences $(\mathrm{P}>0.05)$ were observed in carcass yield, carcass width, fat depth, cooling loss, $\mathrm{pH}$, redness $\left(\mathrm{a}^{*}\right)$, yellowness $\left(\mathrm{b}^{*}\right)$, marbling rate, intramuscular fat, and shear force between Nellore and F1 progeny from Nellore x Araguaia crosses (Table 1). In addition, no significant differences $(\mathrm{P}>0.05)$ were observed for the analyzed sensory characteristics of succulence, tenderness, flavor, and overall quality between Nellore and F1 progeny from Nellore x Araguaia crosses (Table 2).

Slaughter weight, hot weight, chilled carcass weight, carcass length, thigh perimeter, LEA, and Brazilian commercial cuts were significantly greater in $1 / 2$ Nellore $1 / 2$ Araguaia crosses than in Nellore animals, except for leg length and $\mathrm{L}^{*}$, which were significantly greater in Nellore animals $(\mathrm{P}<0.05$; Table 1$)$.

\begin{tabular}{|c|c|c|}
\hline Variable & Nellore & F1 cross: Nellore x Araguaia \\
\hline Slaughter weight $(\mathrm{Kg})^{1}$ & $515.06 \pm 14.31^{\mathrm{b}}$ & $568.68 \pm 11.77^{\mathrm{a}}$ \\
\hline Hot weight $(\mathrm{Kg})^{1}$ & $266.88 \pm 25.22^{b}$ & $296.95 \pm 17.82^{\mathrm{a}}$ \\
\hline Chilled carcass weight $(\mathrm{Kg})^{1}$ & $264.65 \pm 2.33^{\mathrm{b}}$ & $293.35 \pm 1.32^{\mathrm{a}}$ \\
\hline Carcass yield $(\%)^{1}$ & $51.75 \pm 0.01^{\mathrm{a}}$ & $52.20 \pm 0.01^{\mathrm{a}}$ \\
\hline Carcass length $(\mathrm{cm})^{1}$ & $140.41 \pm 3.14^{\mathrm{b}}$ & $143.92 \pm 3.30^{\mathrm{a}}$ \\
\hline Carcass width $(\mathrm{cm})^{1}$ & $49.97 \pm 1.58^{\mathrm{a}}$ & $50.97 \pm 1.64^{\mathrm{a}}$ \\
\hline Leg length $(\mathrm{cm})^{1}$ & $85.29 \pm 1.82^{\mathrm{a}}$ & $84.11 \pm 1.48^{\mathrm{b}}$ \\
\hline Thigh perimeter $(\mathrm{cm})^{1}$ & $108.94 \pm 1.53^{\mathrm{b}}$ & $113.63 \pm 1.83^{\mathrm{a}}$ \\
\hline LEA $\left(\mathrm{cm}^{2}\right)^{1}$ & $58.36 \pm 7.62^{\mathrm{b}}$ & $74.08 \pm 7.26^{\mathrm{a}}$ \\
\hline Retail cuts $(\%)^{1}$ & $60.85 \pm 1.23^{b}$ & $62.44 \pm 0.82^{\mathrm{a}}$ \\
\hline Fat depth $(\mathrm{mm})^{1}$ & $4.11 \pm 1.3^{\mathrm{a}}$ & $3.43 \pm 1.08^{\mathrm{a}}$ \\
\hline Cooling loss $(\%)^{1}$ & $0.82 \pm 0.91^{\mathrm{a}}$ & $1.20 \pm 0.49^{\mathrm{a}}$ \\
\hline $\mathrm{pH} 1$ & $5.90 \pm 0.11^{\mathrm{a}}$ & $5.87 \pm 0.15^{\mathrm{a}}$ \\
\hline Brightness $\left(\mathrm{L}^{*}\right)^{1}$ & $38.18 \pm 1.48^{\mathrm{a}}$ & $36.66 \pm 1.79^{b}$ \\
\hline Redness $\left(\mathrm{a}^{*}\right)^{1}$ & $3.13 \pm 0.50^{\mathrm{a}}$ & $3.21 \pm 0.78^{\mathrm{a}}$ \\
\hline Yellowness $\left(\mathrm{b}^{*}\right)^{1}$ & $3.65 \pm 0.89^{\mathrm{a}}$ & $3.32 \pm 1.10^{\mathrm{a}}$ \\
\hline Marbling score $^{2}$ & $2.41 \pm 0.67^{\mathrm{a}}$ & $2.47 \pm 0.90^{\mathrm{a}}$ \\
\hline Intramuscular fat $(\%)^{1}$ & $1.83 \pm 0.67^{\mathrm{a}}$ & $1.56 \pm 0.55^{\mathrm{a}}$ \\
\hline Shear force $(\mathrm{Kgf})^{1}$ & $16.36 \pm 42.83^{\mathrm{a}}$ & $18.75 \pm 48.52^{\mathrm{a}}$ \\
\hline
\end{tabular}

${ }_{a, b}$ Means followed by the same letter within a line do not differ statistically at a 5\% probability. ${ }^{1}$ Variables analyzed by the t-test. ${ }^{2}$ Variables analyzed by the Mann-Whitney test.

A correlation was made between the unstructured $9 \mathrm{~cm}$ scale used in sensory analysis and a structured 9-point scale in order to interpret these results (Table 3). Regarding succulence, the meat from Nellore and $1 / 2$ Nellore $1 / 2$ Araguaia crosses was classified from slightly dry to not dry or succulent. For tenderness, the trained panelists classified the meat from the animals between slightly hard and not hard or tender. According to the results obtained for flavor, meat from the Nellore animals was classified between slightly insipid to not insipid or savory, and from the $1 / 2$ Nellore $1 / 2$ Araguaia crosses it was classified between not insipid or savory and slightly savory. The meat from the animals was given medium scores for overall quality.

Strong positive correlations were observed between slaughter weight and chilled carcass weight and medium positive correlations were observed between chilled carcass weight and carcass yield, thus, the greater the slaughter weight, the greater the carcass yield of the animal. Positive correlations were also observed between slaughter weight and carcass length, thus, the greater the slaughter weight, the greater the carcass length (Table 4).

Leg length was positively correlated with slaughter weight, chilled carcass weight, carcass yield, carcass length, and carcass width. Yet thigh perimeter showed a medium posi- 
tive correlation with slaughter weight and chilled carcass weight, carcass length, carcass width, and leg length. The LEA variable showed a low positive correlation with slaughter weight and thigh perimeter, indicating that the greater the slaughter weight, the greater the thigh perimeter, LEA, and amount of meat on the carcass due to a medium positive correlation between LEA and percentage of Brazilian retail cuts (Table 4). A medium negative correlation was observed between the percentage of Brazilian retail cuts and fat depth, indicating the greater amount of Brazilian retail cuts, the smaller the fat depth of the animal (Table 4).

Table 2. Means and standard deviations for sensory analysis (in $\mathrm{cm}$ ) of Nellore and F1 progeny of crosses between Nellore and Araguaia.

\begin{tabular}{lcc}
\hline Variable & Nellore & F1 cross between Nellore x Araguaia \\
\hline Succulence & $4.18 \pm 1.49^{\mathrm{a}}$ & $4.46 \pm 1.14^{\mathrm{a}}$ \\
Tenderness & $4.35 \pm 1.24^{\mathrm{a}}$ & $4.56 \pm 1.25^{\mathrm{a}}$ \\
Flavor & $4.90 \pm 1.40^{\mathrm{a}}$ & $5.39 \pm 1.09^{\mathrm{a}}$ \\
Overall quality & $4.93 \pm 1.32^{\mathrm{a}}$ & $5.14 \pm 1.24^{\mathrm{a}}$ \\
\hline
\end{tabular}

a,b Means followed by the same letter within a line do not differ statistically at a $5 \%$ probability by the Friedman test.

Table 3. A structured 9-point scale used for sensory analysis.

\begin{tabular}{ll}
\hline 9-point scale & Structured scale (succulence/ tenderness/ flavor/ overall quality) \\
\hline 1 & Extremely dry/ hard/ insipid/ low quality \\
2 & Very dry/ hard / insipid/ low quality \\
3 & Moderately dry/ hard / insipid/ low quality \\
4 & Slightly dry/ hard / insipid/ low quality \\
5 & Not dry/ hard/ insipid/ low quality nor succulent/ tender/ savory/ high quality \\
6 & Slightly succulent/ tender/ savory/ high quality \\
7 & Moderately succulent / tender/ savory/ high quality \\
8 & Very succulent/ tender/ savory/ high quality \\
9 & Extremely succulent/ tender/ savory/ high quality \\
\hline
\end{tabular}

Table 4. Correlation coefficient between carcass traits and meat quality of Nellore and F1 crosses between Nellore and Araguaia.

\begin{tabular}{|c|c|c|c|c|c|c|c|c|c|c|c|c|c|c|c|c|}
\hline & CCW & CY & $\mathrm{CL}$ & $\mathrm{CW}$ & LL & TT & LEA & BRC & $\mathrm{COL}$ & $\mathrm{pH}$ & FD & IMF & $\mathrm{L}$ & $\mathrm{a}$ & $\mathrm{b}$ & SF \\
\hline PA & $0.914^{*}$ & 0.447 & $0.827^{*}$ & $0.627 *$ & $0.555^{*}$ & $0.883 *$ & $0.621 *$ & 0.187 & 0.384 & 0.225 & 0.138 & 0.226 & -0.242 & $-0.489 *$ & -0.155 & $0.541^{*}$ \\
\hline CCW & & $0.761^{*}$ & $0.797 *$ & $0.722 *$ & $0.656^{*}$ & $0.881^{*}$ & $0.593 *$ & 0.229 & 0.317 & 0.312 & 0.075 & 0.062 & -0.349 & $-0.601 *$ & -0.044 & $0.583^{*}$ \\
\hline CY & & & $0.545^{*}$ & $0.603 *$ & $0.516^{*}$ & $0.574^{*}$ & 0.385 & 0.258 & 0.226 & 0.259 & 0.072 & -0.075 & -0.335 & $-0.568^{*}$ & $-0.467 *$ & 0.470 \\
\hline CL & & & & $0.560 *$ & $0.551^{*}$ & $0.743^{*}$ & $0.612 *$ & 0.275 & 0.381 & 0.024 & 0.159 & -0.088 & -0.153 & 0.042 & -0.017 & 0.190 \\
\hline $\mathrm{CW}$ & & & & & $0.498^{*}$ & $0.801 *$ & 0.309 & 0.086 & 0.065 & 0.040 & 0.007 & 0.083 & -0.094 & -0.301 & -0.035 & $0.522^{*}$ \\
\hline LL & & & & & & $0.701^{*}$ & 0.209 & -0.032 & 0.426 & 0.129 & -0.003 & -0.247 & 0.341 & -0.328 & $-0.472 *$ & 0.257 \\
\hline TT & & & & & & & $0.667^{*}$ & 0.291 & 0.238 & 0.373 & 0.029 & -0.161 & -0.265 & -0.418 & $-0.528^{*}$ & $0.522 *$ \\
\hline LEA & & & & & & & & $0.813^{*}$ & 0.395 & 0.198 & -0.267 & 0.119 & -0.262 & -0.296 & -0.264 & 0.304 \\
\hline BRC & & & & & & & & & 0.280 & 0.281 & $-0.730^{*}$ & -0.432 & -0.296 & $0.505^{*}$ & -0.065 & 0.301 \\
\hline $\mathrm{COL}$ & & & & & & & & & & $0.527^{*}$ & -0.022 & -0.180 & -0.265 & -0.193 & -0.426 & 0.263 \\
\hline $\mathrm{pH}$ & & & & & & & & & & & 0.089 & 0.039 & -0.068 & -0.257 & -0.251 & -0.103 \\
\hline FD & & & & & & & & & & & & 0.212 & 0.216 & 0.172 & -0.270 & -0.433 \\
\hline IMF & & & & & & & & & & & & & 0.391 & 0.094 & 0.138 & -0.181 \\
\hline L & & & & & & & & & & & & & & 0.305 & $0.600 *$ & -0.157 \\
\hline $\mathrm{a}$ & & & & & & & & & & & & & & & 0.526 & -0.443 \\
\hline b & & & & & & & & & & & & & & & & 0.093 \\
\hline
\end{tabular}

$* \mathrm{P}<0.05$ : correlation exists; $\mathrm{SW}$ - slaughter weight; $\mathrm{CCW}$ - chilled carcass weight; $\mathrm{CY}$ - carcass yield; $\mathrm{CL}$ - carcass length; CW - carcass width; LL - leg length; TT - thigh perimeter; LEA - loin eye area; BRC - Brazilian retail cuts; COL - cooling loss; FD - fat depth; IMF - intramuscular fat; SF - shear force. 
According to the sensory analysis, a positive correlation was observed between all the variables studied, indicating that these traits are interdependent and each one contributes to the acceptance of this meat (Table 5).

Table 5. Correlation coefficient between the sensory characteristics evaluated in the sensory analysis of Nellore and F1 crosses between Nellore and Araguaia.

\begin{tabular}{lccc}
\hline & Tenderness & Flavor & Overall Quality \\
\hline Succulence & $0.725^{*}$ & $0.653^{*}$ & $0.664^{*}$ \\
Tenderness & & $0.725^{*}$ & $0.632^{*}$ \\
Flavor & & & $0.881^{*}$ \\
\hline
\end{tabular}

$* \mathrm{P}<0.05$ : correlation exists.

\section{DISCUSSION}

The $1 / 2$ Nellore $x 1 / 2$ Araguaia crosses had a mean slaughter weight $53.62-\mathrm{kg}$ greater per animal than the Nellore cattle, likely due to the higher percentage of European genetic background of these animals. Lopes et al. (2012) found 7.04\% greater slaughter weights in crossbred Red Norte when compared to Nellore cattle. Similar results were also observed by Pereira et al. (2009), who found greater slaughter weight in $1 / 2$ Aberdeen Angus X $1 \frac{1}{2}$ Nellore cattle compared to Nellore cattle.

Mean hot carcass weight was observed to be $30.07 \mathrm{~kg}$ greater in $1 / 2$ Nellore $\mathrm{x} 1 / 2$ Araguaia animals compared to Nellore animals. Pereira et al. (2009) found hot carcass weight to be $7.73 \%$ greater in $1 / 2$ Aberdeen Angus x $1 / 2$ Nellore cattle compared to Nellore cattle. However, Lopes et al. (2012) found no statistical difference in hot carcass weight between Red Norte and Nellore breeds.

As observed for slaughter weight and hot carcass weight, the mean chilled carcass weight of $1 / 2$ Nellore $\times 1 / 2$ Araguaia cattle was $28.70 \mathrm{~kg}$ greater than that for Nellore cattle. Rocha Junior et al. (2010) found similar values for chilled carcass weight in Nellore animals.

Even though the $1 / 2$ Nellore $\mathrm{x} 1 / 2$ Araguaia animals showed higher slaughter weight, hot carcass weight, and chilled carcass weight, no differences $(P>0.05)$ were observed for carcass yield, possibly due to the lowed gastrointestinal tract of Nellore reducing the differences in carcass yield (Table 1). Similar carcass yields have been previously reported; Vaz et al. (2008) observed carcass yields of 51\% for Aberdeen Angus cattle and Rocha Júnior et al. (2010) recorded carcass yields of 52.12\% for Nellore. Interestingly, Lopes et al. (2012) found higher carcass yields for Nellore cattle when compared to crossbred Red Norte. However, according to Pereira et al. (2009), no statistical differences were found between $1 / 2$ Aberdeen Angus and Nellore, similar to the results found in this study.

The crossbred animals in the current study had carcass lengths that were on average $3.51 \mathrm{~cm}$ longer than those of the Nellore animals. Similar results were presented by Pereira et al. (2009), where $1 / 2$ Aberdeen Angus x $1 / 2$ Nellore animals had carcass lengths $6 \mathrm{~cm}$ longer than those of Nellore, possibly due to the European genetic composition. The Nellore animals were $1.18 \mathrm{~cm}$ longer than the crossbred animals; however, the $1 / 2$ - Nellore $1 / 2 \mathrm{x}$ Araguaia animals presented thigh perimeters that were $4.69 \mathrm{~cm}$ larger than the Nellores. Thus, the Nellore animals were greater in length with a smaller proportion of thigh perimeter and consequently smaller LEA and smaller meat proportion.

The LEA of crossbred animals was approximately $16 \mathrm{~cm}^{2}$ larger than the LEA of Nellore animals, which may be due to heterosis resulting from crossing the European and zebu breeds. Lopes et al. (2012) claim that the increase in LEA is due to a higher rate of growth pre- 
sented by European animals compared with the zebu breeds. According to Arrigoni et al. (2004), Bos taurus and Bos indicus crossbred animals present higher growth rates in cattle due to the higher percentage of European genetic composition. Pereira et al. (2009) claim that animals that result from crossing European and zebu cattle have higher LEA values, demonstrating the efficiency of the crossing on increased muscularity in the animals. A fact also confirmed by a higher percentage of Brazilian retail cuts in the $1 / 2$ Nellore $x 1 / 2$ Araguaia animals in the current study.

The animals in the current study showed mean fat depth greater than $3 \mathrm{~mm}$, which is consistent with the parameters set by the slaughterhouses to ensure the prices paid to producers are not penalized (Luchiari Son, 2000). Although the zebu cattle present early fat deposition when compared with European animals (Restle et al., 2002), no statistical differences (P $>0.05)$ were observed for this variable in the current study.

Furthermore, no statistical difference $(\mathrm{P}>0.05)$ was observed in cooling loss between the two breeds. This variable may have been minimized by the considerable fat depth and the $\mathrm{pH}$ of the meat being located above the isoelectric point of the proteins of the meat, which is around 5.2-5.3, according to Rodrigues Filho et al. (2014). These authors further state that for $\mathrm{pH}$ values greater than 5.5 there is a large amount of negative charges favoring repulsion of protein filaments. This provides more space for the water molecules, increasing the capacity of water retention and consequently reducing losses during cooling. Lopes et al. (2012) also found no significant difference in cooling loss between the Nellore and Red Norte, claiming that this was due to the subcutaneous fat distribution level presented by the animals, which acts as an insulator aiding fluid retention during cooling. Neath et al. (2007) stated that cattle finished on pastures have less glycogen in pre-slaughter, resulting in higher meat $\mathrm{pH}$. According to Lopes et al. (2012), zebu animals are more easily stressed at slaughter, contributing to a higher consumption of glycogen, resulting in a higher final $\mathrm{pH}$ of meat, which may have influenced the results of the current study.

Although $\mathrm{pH}$ values presented here were above those recommended by Roça (1997), cited by Lopes et al. (2012), between 5.4 and 5.8, these values were accepted, because Lawrie (2005) stated that meat only tends to appear dark, turgid and not exuding when the $\mathrm{pH}$ is greater than 6 . Based on these results, the mean values of $\mathrm{L}^{*}$ for both genetic groups in the current study were considered normal for color according to Abularach et al. (1998).

The mean redness $\left(\mathrm{a}^{*}\right)$ of meat cuts was considered low in relation to yellowness $\left(b^{*}\right)$, and the mean observed in the current study was considered normal for Nellore and low for crossbred animals according to Abularach et al. (1998). The mean values for the variable $\mathrm{L}^{*}$ were observed to be significantly higher $(\mathrm{P}<0.05)$ in the Nellore animals compared to the crossbred animals, but both values were within the range of normal brightness according to Abularach et al. (1998). Rossato et al. (2010) also observed normal values of L*, a*, and b* in Nellore and Angus animals, the second showing a higher intensity of $b^{*}$.

The marbling rate of meat was visually evaluated and determined by assigning 1 for beef with low intramuscular fat and 6 for beef with high intramuscular fat. Both genetic groups had meat between light and not much intramuscular fat based on the marble grade of AMSA (2001), as cited by Felício (2010).

The intramuscular fat content of the meat was low and did not differ significantly between the two genetic cattle groups. The intramuscular fat content observed here is classed as low according to Campion et al. (1975), who state that the lipid content of the meat should range from 2.9 to $3.0 \%$ to ensure the flavor of the meat is not compromised. Abularach et al. (1998) found a similar amount of intramuscular fat in Nellore (1.71\%) also using samples of 
L. dorsi (muscle portion). Although the consumption of high levels of lipids may damage human health and there is a tendency to reduce the consumption of high fat products, the lipid component of meat performs important functions related to the sensory quality of the food (Pacheco et al., 2005). The intramuscular fat attribute may be responsible for the meat flavor being classified between slightly insipid and not insipid or savory for Nellore and between not insipid or savory and slightly savory for the crossbred cattle in the current study. As the sensory characteristics of the meat are highly correlated, a characteristic that shows a decrease in its grade may result in a decrease in the other characteristics of the meat. Therefore, quality meat production requires careful consideration of all these factors, aiming to maximize each one to ensure meat will have good levels of acceptance.

In the present study, no differences were observed in the sensory variables between the two cattle groups and among the trained panelists who evaluated the meat between slightly hard and not hard or tender.

Furthermore, no differences $(\mathrm{P}>0.05)$ were observed for the variables of cooling loss, $\mathrm{a}^{*}$, and $\mathrm{b}^{*}$ between the two cattle groups and both showed normal values for $\mathrm{L}^{*}$. All of these characteristics are closely related to texture, and no differences were observed in shear force (P $>0.05$; Table 1). However, previous studies have observed differences in shear force between cattle groups. Pereira et al. (2009) found that Nellore cattle had greater shear force compared to $1 / 2$ Nellore x $1 / 2$ Aberdeen Angus, and Rossato et al. (2010) found a higher shear force for Nellore compared to Angus cattle.

The results of the current study indicate that the higher the slaughter weight, chilled carcass weight, carcass length, carcass width, leg length, and thigh perimeter, in other words the greater the carcass traits, the greater the yield. In addition, the higher the slaughter weight and thigh perimeter, the larger the LEA and the greater the percentage of Brazilian retail cuts. According to Restle et al. (1999), this is probably due to these traits being correlated with animal growth rate. A medium negative correlation was also observed between the percentage of Brazilian retail cuts and fat depth, i.e., the greater the amount of retail cuts, the lower the fat depth, due to the late deposition of fat, where subcutaneous fat is the last to increase in proportion (Luchiari Son, 2000).

In conclusion, crosses between Nellore and Araguaia cattle increased slaughter weight, hot carcass weight, chilled carcass weight, carcass length, thigh perimeter, LEA, and the percentage of Brazilian retail cuts when compared to Nellore cattle, yet crossing did not influence the meat's sensory characteristics. The Nellore and Araguaia crossbreed is an alternative for farmers that seek greater hot carcass weight, which is the main form of compensation to livestock producers, without influencing the meat's sensory characteristics.

\section{ACKNOWLEDGMENTS}

We would like to thank Frigorífico JBS S/A, Barra do Garças-MT unit for granting the industrial slaughterhouse structure and for the permission to collect animal data. We also thank Fundação de Amparo à Pesquisa do Estado de Minas Gerais (FAPEMIG) for granting the master's scholarship.

\section{REFERENCES}

ABIEC (2013). Associação Brasileira das Indústrias Exportadoras de Carne. Disponível em [http://www.abiec.com.br/3
rebanho.asp]. Acesso em 13 outubro, 2013.
Abularach MLS, Rocha CE and Felício PE (1998). Características de qualidade do contrafilé (m. L. dorsi) de touros jovens 
da raça Nelore. Ciênc. Tecnol. Aliment. 18: 205-210.

American Meat Science Association (AMSA) (2001). Meat Evaluation Handbook. American Meat Science Association, Savoy.

ANFAR (2009). Compêndio Brasileiro de Alimentação Animal-Métodos Analíticos. ANFAR, São Paulo.

Arrigoni MB, Alves Júnior A, Dias PMA, Martins CL, et al. (2004). Desempenho, fibras musculares e carne de bovinos jovens de três grupos genéticos. Pesqui. Agropecu. Bras. 39: 1033-1039.

BRAZIL (1997). Ministério da Agricultura, Pecuária e Abastecimento. Departamento de Inspeção de Produtos de Origem Animal. Decreto n. 30, 691. Aprova o Regulamento da Inspeção Industrial e Sanitária de Produtos de Origem Animal (RIISPOA). Diário Oficial da União de 5 de julho de 1997, Brasília.

Bridi AM (2002). Normas de Avaliação, Classificação e Tipificação de Carnes e Carcaças. Universidade Estadual de Londrina, Londrina.

Campion DR, Crouse JD and Dikeman ME (1975). Predictive value of USDA beef quality grade factors for cooked meat palatability. J. Food Sci. 40: 1225-1228.

City Brazil (2013). Clima/temperatura-Torixoréu-MT. Disponível em [http://www.citybrazil.com.br/mt/torixoreu/geral_ detalhe.php?cat=3]. Acesso em 26 dezembro, 2013.

de Souza VLF, Ayer IM, Gasparino E, Cardozo RM, et al. (2010). Cruzamento industrial sobre as características de carcaça e da carne de novilhas precoces. Acta Sci. Anim. Sci. 32: 447-453.

Equipe Estatcamp (2014). Software Action. Estatcamp-Consultoria em estatística e qualidade, São Carlos-SP, Brazil. Disponível em [http://www.portalaction.com.br]. Acesso em 05 novembro, 2014.

Felício PE (2010). Classificação e tipificação de carcaças bovinas. In: Bovinocultura de Corte (Pires AV). Editora FEALQ, Piracicaba, 1263-1282.

Felício PE and Allen DM (1981/1982). Previsão de rendimentos em carne aproveitável da carcaça de novilhos Zebu. Col. Inst. Tecnol. Aliment. 12: 203-217.

Freitas AK, Restle J, Pacheco PS, Padua JT, et al. (2008). Características de carcaças de bovinos Nelore inteiros vs castrados em duas idades, terminados em confinamento. Rev. Bras. Zootecn. 37: 1055-1062.

Lawrie RA (2005). Ciência da carne. 6th edn. Artmed, Porto Alegre.

Lopes LS, Ladeira MM, Machado Neto OR, Paulino PVR, et al. (2012). Características de carcaça e cortes comerciais de tourinhos Red Norte e Nelore terminados em confinamento. Rev. Bras. Zootecn. 41: 970-977.

Luchiari Son A (2000). Pecuária da carne bovina. R Vieira Gráfica e Editora, São Paulo.

Neath KE, Del Barrio NA, Lapitan RM, Herrera JR, et al. (2007). Difference in tenderness and pH decline between water buffalo meat and beef during postmortem aging. Meat Sci. 75: 499-505.

Pacheco PS, Restle J, da Silva JHS, Brondani IL, et al. (2005). Composição física da carcaça e qualidade da carne de novilhos jovens e superjovens de diferentes grupos genéticos. Rev. Bras.Zootecn. 34: 1691-1703.

Pereira PMRC, Pinto MF, de Abreu UGP and de Lara JAF (2009). Características de carcaça e qualidade de carne de novilhos superprecoces de três grupos genéticos. Pesqui. Agropecu. Bras. 44: 1520-1527.

Perotto D, Abrahão JJS and Moletta JL (2000). Características quantitativas de carcaça de bovinos Zebu e de cruzamentos Bos taurus x Zebu. Rev. Bras. Zootecn. 29: 2019-2029.

R Core Team (2013). R: A language and environment for statistical computing. R Foundation for Statistical Computing, Vienne, Austria. Disponível em [http://www.r-project.org]. Acesso em 01maio, 2013.

Restle J, Vaz FN, Quadros ARB, Muller L (1999). Características de carcaça e da carne de novilhos de diferentes genótipos Hereford x Nellore. Rev. Bras. Zootecn. 28: 1245-1251.

Restle J, Vaz FN, Feijó GLD, Brondani IL, et al. (2000). Características de carcaça de bovinos de corte inteiros ou castrados de diferentes composições raciais Charolês e Nelore. Rev. Bras. Zootecn. 29: 1371-1379.

Restle J, Pascoal LL, Faturi C, Alves Filho DC, et al. (2002). Efeito do grupo genético e da heterose nas características quantitativas da carcaça de vacas de descarte terminadas em confinamento. Rev. Bras. Zootecn. 31: 350-362.

Roça RO (1997). Tecnologia da carne e produtos derivados. Faculdade de Ciências Agronômicas, Botucatu.

Rocha Júnior VR, Silva FV, de Barros RC, dos Reis ST, et al. (2010). Desempenho e características de carcaça de bovinos Nelore e Mestiços terminados em confinamento. Rev. Bras. Saúde Prod. Anim. 11: 865-875.

Rodrigues Filho M, Péres JRO, Ramos EM, Rodrigues NEB, et al. (2014). Características da carne de tourinhos Red Norte suplementados com óleos de fritura e soja terminados em confinamento. Rev. Bras. Saúde Prod. Anim. 15: 62-73.

Rossato LV, Bressan MC, Rodrigues EC, Gama LT, et al. (2010). Parâmetros físico-químicos e perfil de ácidos graxos da carne de bovinos Angus e Nelore terminados em pastagem. Rev. Bras. Zootecn. 39: 1127-1134.

Silva DJ, Queiroz AC and Neves AR (2002). Análise de alimentos: métodos químicos e biológicos. 3rd edn. Editora Universidade Federal de Viçosa, Viçosa.

Vaz FN, Restle J, Metz PAM and Moletta JL (2008). Características de carcaça de novilhos Abeerden Angus terminados em pastagem cultivada ou confinamento. Ciênc. Anim. Bras. 9: 590-597.

Genetics and Molecular Research 14 (2): 5379-5389 (2015)

CFUNPEC-RP www.funpecrp.com.br 